\title{
Analisis Perkembangan Nilai Agama-Moral Siswa Usia Dasar (Tercapai) Studi Kasus di MI Ma'arif Bego
}

\author{
Iswatun Khoiriah ${ }^{1}$, Ifat $\mathrm{Nabilah}^{2}$, dan Suyadi ${ }^{3}$ \\ Universitas Islam Negeri Sunan Kalijaga Yogyakarta \\ email:1iswatunkhoiriah@gmail.com, 2nabilahifat95@gmail.com, 3yadi.uinjogja@gmail.com
}

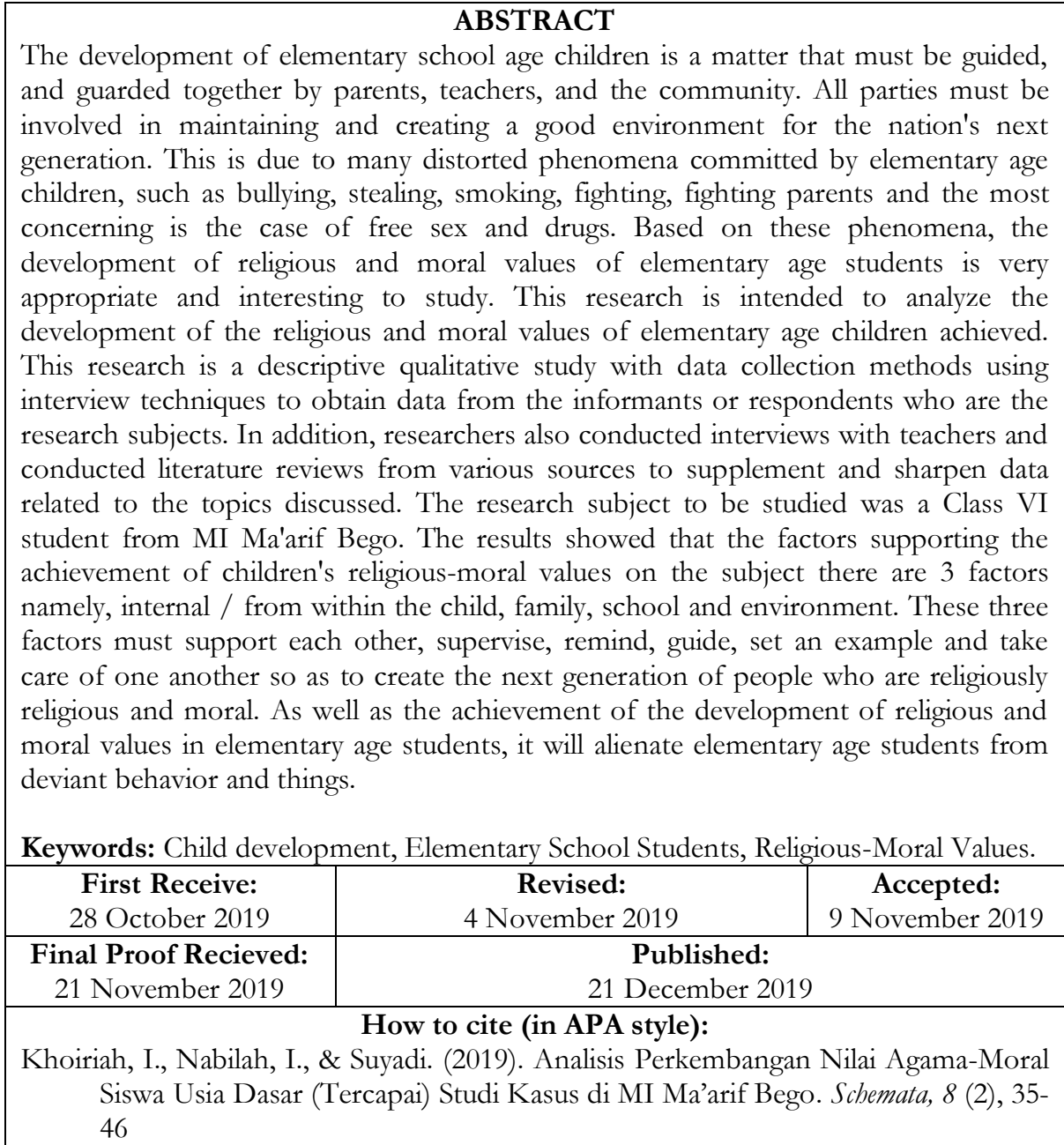

\section{PENDAHULUAN}

Nilai agama dan moral pada anak usia sekolah dasar dapat diartikan sebagai perubahan psikis yang dialami anak didik terkait kemampuan memahami dan menerapkan perilaku yang sesuai ajaran agama yang dianutnya. Tingkah laku, tutur kata, pola pikir sering dikaitkan dengan moral seseorang, sedangkan moral agama berkaitan dengan hal-hal yang dianut dan bersumber dari Al-Qur'an dan Hadits. Nilai agama dan moral adalah pondasi awal bagi anak dalam menjalani kehidupan dari berbagai hal yang mungkin terjadi baik dan buruk dalam kehidupan sehari-hari. 
Iswatun K., Ifat N., Suyadi, Analisis Perkembangan Nilai Agama-moral Siswa Usia Dasar (tercapai)...

Berbagai fenomena perilaku menyimpang sering terlihat dalam kehidupan seharihari pada anak jaman sekarang. Contoh kasus dugaan pengeroyokan siswa SD di Kediri oleh temannya saat bermain sepak bola ditengarai hanya karena melakukan gol bunuh diri terjadi pada Januari 2018. ${ }^{1}$ Masalah terkait nilai agama dan moral anak bermacam-macam, seperti: bullying, mencuri, merokok, tawuran, melawan orang-tua, seks bebas, narkoba dan sebagainya semakin meresahkan masyarakat khususnya guru dan orang tua. Dapat dikatakan bahwasanya masalah yang juga penting selain meningkatkan kualitas kognitif anak adalah masalah akhlak dan karakter anak. Nilai agama dan moral seorang anak dapat kita ketahui dengan hanya melihat dan memperhatikan sikap ataupun tingkah laku anak sehari-hari yang mencerminkan kepribadiannya.

Pada masa sekolah dasar, anak masih suka mengamati dan meniru apa yang menjadi kebiasaan di lingkungannya. Masa anak-anak usia sekolah dasar juga merupakan pondasi lanjutan dari masa usia dini dalam menanamkan nilai agama-moral sebagai bekal kehidupan. Hal-hal apa saja yang menjadi pendukung dari dalam dan luar sehingga anak mencapai nilai agama dan moral sesuai dengan perkembangannya.

Pendidikan Moral memerlukan keterlibatan semua aspek kehidupan manusia, sehingga penekanan tidak hanya pada kognitifnya saja. Namun pendidikan moral agama bagi anak usia sekolah dasar harus disesuaikan dengan perkembangan jiwa anak, mengembangkan seluruh aspek kehidupan manusia. ${ }^{2}$ Penyimpangan perilaku anak usia dasar yang saat ini sangat meresahkan dunia pendidikan, tingkat Dasar khususnya, terjadi karena lemahnya pondasi nilai agama dan moral mereka.Akan tetapi, ketika peneliti observasi keadaan di MI Ma'arif Bego, Kecamatan Depok, Kabupaten Sleman terlihat pemandangan yang berbeda. Ketika sampai di Madrasah, siswa tengah salat dhuha dan tadarus bersama serta ketika kami melewati beberapa siswa mereka senyum dan menyapa kami walaupun belum kenal. Hal ini menjadi menarik untuk ditelusuri bagaimana keseharian mereka baik di lingkungan sekolah, keluarga dan masyarakat serta bagaimana mereka dapat mencapai tahap perkembangan nilai agama dan moral yang dapat dikatakan mereka telah berhasil mencapainya untuk seusia dasar saat ini. Peneliti akan meneliti dengan judul "Analisis Perkembangan Nilai Agama-Moral Siswa Usia dasar (tercapai) Studi Kasus di MI Ma’arif

1 C Damanik, "gara-gara cetak gol bunuh diri siswa SD dianiaya teman-teman hingga masuk," https:/ / www.kompas.com/. Diambil kembali dari https:/ / regional.kompas.com/ read/2018/01/29/10365701/gara-garacetak-gol-bunub-diri-siswa-sd-dianiaya-teman-teman-bingga-masuk., pada tanggal 2018, 0129.

2 S. D Kusrahmadi, "Pentingnya Pendidikan Moral Bagi Anak Sekolah Dasar," Dinamika Pendidikan (2007). hlm. 118-129.

\section{Copyright (C) 2019 Schemata Journal}

Available online at http://journal.uinmataram.ac.id/index.php/schemata 
Iswatun K., Ifat N., Suyadi, Analisis Perkembangan Nilai Agama-moral Siswa Usia Dasar (tercapai)...

Bego. Sehingga, penelitian ini bertujuan untuk menganalisis perkembangan nilai agama dan moral siswa Usia Dasar yang tercapai.

\section{LANDASAN TEORI}

\section{Karakteristik Anak Usia Dasar}

Usia sekolah dasar (7 tahun-12 tahun) merupakan tahapan penting bagi perkembangan seorang peserta didik. Masa sekolah dasar menjadi masa yang cukup panjang dalam pendidikan. Sebagai kelanjutan dari pendidikan sebelumnya (usia dini), pada rentang usia ini juga menjadi fundamental bagi kesuksesan perkembangan pendidikan selanjutnya.

Karakteristik umum anak pada dasarnya menggambarkan tentang kondisi siswa seperti usia, kelas, pekerjaan dan gender. Karakteristik siswa merupakan ciri khusus yang dimiliki masing-masing siswa baik sebagai individu atau kelompok sebagai pertimbangan dalam proses pengorganisasian pembelajaran. ${ }^{3}$ Masa usia sekolah dasar sering disebut sebagai masa intelektual atau masa keserasian bersekolah. Pada masa keserasian bersekolah ini secara relatif, anak-anak lebih mudah di didik daripada masa sebelum dan sesudahnya. ${ }^{4}$

\section{Perkembangan, Nilai Agama dan Moral}

Perkembangan dapat diartikan sebagai proses perubahan yang progresif dan kontinyu (berkesinambungan) dalam diri individu mulai dari lahir hingga mati (the progressive and continous change in the organism from birth to death). Perkembangan dapat diartikan juga sebagai perubahan yang dialami individu atau organisme menuju tingkat kedewasaan atau kematangan (maturattion) yang berlangsung secara sistematis, progesif, dan berkesinambungan baik fisik (jasmaniah) maupun psikis (rohaniah). ${ }^{5}$

Agama merupakan tuntutan hidup yang dapat membebaskan manusia dari kekacauan. Di dunia barat agama sering disebut sebagai religion yang berarti melakukan suatu perbuatan dengan penuh penderitaan atau mati-matian. Dalam Islam sendiri, agama berupa wahyu Allah yang diturunkan melalui para Nabi yang berisi perintah dan larangan. ${ }^{6}$

\footnotetext{
${ }^{3}$ W Winkel, Psikologi Pengajaran (Jakarta: Grasindo, 1996).

${ }^{4}$ S Yusuf, Psikologi Perkembangan Anak dan Remaja (Bandung: PT Remaja Rosda Karya, 2016). hlm. 24.

${ }^{5}$ Ibid., hlm. 15. 2005). hlm. 10.

${ }^{6} \mathrm{~S}$ Yusuf, Psikologi Belajar Agama: Prespektif Pendidikan Agama Islam (Bandung: Pustaka Bani Quraisy,
} 
Iswatun K., Ifat N., Suyadi, Analisis Perkembangan Nilai Agama-moral Siswa Usia Dasar (tercapai)...

Nilai-nilai atau kaidah yang terkandung dalam agama selaras dengan fitrah manusia sebagai mahluk beragama. Seseorang yang telah berpedoman agama sebagai dasar rujukan perilaku, dan sebagai kompas kehidupan maka ia telah terbebas dari kebodohan dan memperoleh pencerahan hidup.

Istilah moral berasal dari bahasa Latin "mores" yang artinya tata cara dalam kehidupan, adat istiadat, atau kebiasaan. Moral pada dasarnya merupakan rangkaian nilai tentang berbagai macam perilaku yang harus dipatuhi. ${ }^{7}$ Sedangkan moralitas merupakan kemauan untuk menerima dan melakukan peraturan, nilai-nilai atau prinsip-prinsip moral. Nilai-nilai moral itu seperti seruan untuk berbuat kebaikan dan larangan untuk berbuat keburukan. ${ }^{8}$ Perkembangan moral ialah kelangsungan mempelajari standar moral serta norma sosial. Situasi yang fungsionallah yang melandasi ekspresi pertimbangan moral. ${ }^{9}$

Moral agama mempunyai kekuatan yang lebih besar dalam memberikan pengaruh terhadap kehidupan individu. Moral agama harus bersumber dari nash Al-Qur'an yang dijelaskan oleh Hadits Nabi saw dan perkembangan pemikiran ulama yang islami. Moral agama sebagai disiplin ilmu yang berarti ilmu pengetahuan yang mengkaji baik dan buruknya tingkah laku, pola pikir, tutur kata manusia dengan standar Al-Qur'an. ${ }^{10}$

\section{Tahap Perkembangan Agama dan Moral Anak Usia Dasar}

Tahapan perkembangan agama yang terkenal menurut James Fowler adalah theory of faith. Teori ini, Fowler mengusulkan 6 tahap teori perkembangan agama yang dihubungkan dengan teori-teori perkembangan Erikson, Piaget, dan Kohlberg.

Tabel 1. Tahap Perkembangan Agama menurut James Fowler ${ }^{11}$

\begin{tabular}{lll}
\hline \multicolumn{1}{c}{ Tahap } & \multicolumn{1}{c}{ Usia } & \multicolumn{2}{c}{ Karakteristik } \\
\hline Tahap 1 & Awal masa & - Gambaran intituitif dari kebaikan dan \\
Intuitive-projective faith & anak-anak & kejahatan; fantasi dan kenyataan adalah sama \\
& & - Pemikiran lebih logis dan konkrit; kisah- \\
Tahap 2 & Akhir masa & kisah agama diinterpretasikan secara harfiah; \\
Mythical-literal faith & anak-anak & tuhan digambarkan sebagai figur orang tua.
\end{tabular}

${ }^{7}$ M Asrori, Psikologi Pembelajaran (Bandung: CV Wacana Prima, 2012). hlm. 155.

${ }^{8}$ Yusuf, Psikologi Perkembangan Anak dan Remaja. (Bandung: PT. Remaja Rosda Karya), hlm. 132.

${ }^{9}$ W Kurtinez, Moralitas, Perilaku Moral dan Perkembangan Moral (Jakarta: UI Press, 1992). hlm. 300.

${ }^{10}$ Muslih, "Moral Agama, Suluh Kepribadian Pemuda Menghadapi Arus Budaya Massa," Dirjen Bimbaga Islam (1987). hlm. 78.

${ }^{11}$ Desmita, Psikologi Perkembangan (Bandung: PT Remaja Rosda Karya, 2006). hlm. 209. 
Iswatun K., Ifat N., Suyadi, Analisis Perkembangan Nilai Agama-moral Siswa Usia Dasar (tercapai)...

\begin{tabular}{|c|c|c|}
\hline $\begin{array}{l}\text { Tahap } 3 \\
\text { Synthetic-conventional faith }\end{array}$ & $\begin{array}{l}\text { Awal masa } \\
\text { remaja }\end{array}$ & $\begin{array}{l}\text { - Pemikiran lebih abstrak; menyesuaikan diri } \\
\text { dengan keyakinan agama orang lain. }\end{array}$ \\
\hline $\begin{array}{l}\text { Tahap } 4 \\
\text { Individuative-reflective } \\
\text { faith }\end{array}$ & $\begin{array}{l}\text { Akhir masa } \\
\text { remaja dan } \\
\text { awal masa } \\
\text { dewasa }\end{array}$ & $\begin{array}{l}\text { - Untuk pertama kali individu mampu } \\
\text { memiliki tanggungjawab penuh terhadap } \\
\text { keyakinan agama mereka; menjelajahi } \\
\text { kedalaman pengamalan nilai-nilai dan } \\
\text { keyakinan agama seseorang. }\end{array}$ \\
\hline Conjuctive faith & $\begin{array}{l}\text { Pertengahan } \\
\text { masa } \\
\text { dewasa }\end{array}$ & $\begin{array}{l}\text { - Lebih terbuka terhadap pandangan- } \\
\text { pandangan paradoks dan bertentangan; } \\
\text { berasal dari kesadaran akan batasan dan } \\
\text { pembatasan seseorang }\end{array}$ \\
\hline $\begin{array}{l}\text { Tahap } 6 \\
\text { Universalizing }\end{array}$ & Akhir masa & $\begin{array}{l}\text { - Sistem kepercayaan transdental untuk } \\
\text { dewasa mencapai perasaan ketuhanan; } \\
\text { peristiwa-peristiwa konflik tidak semuanya } \\
\text { dipandang sebagai paradoks. }\end{array}$ \\
\hline
\end{tabular}

Perkembangan beragama pada fase masa anak (usia Sekolah Dasar: 6 tahun - 12 tahun) berdasarkan kesadaran beragama anak menurut Syamsu Yusuf sebagai berikut:

Tabel 2. Perkembangan dan aktualisasi beragama fase masa anak ${ }^{12}$

\begin{tabular}{ll}
\hline Nilai-nilai Agama & \multicolumn{1}{c}{ Sikap dan Perilaku Anak } \\
\hline Aqidah (Keyakinan) & - Bukan hasil pemikiran \\
& - Merupakan sikap emosi yang berhubungan erat \\
& dengan kebutuhan jiwa akan kasih sayang dan \\
& perlinduungan. \\
- & Mengetahui sifat-sifat Tuhan Maha Pengasih dan \\
& Penyayang-Nya. \\
& - Mengetahui sifat Tuhan Maha menghukum, \\
& mengadzab hingga siksa neraka. \\
\hline - Perluasan, pengembangan materi pendidikan \\
- sebelumnya. \\
\hline
\end{tabular}

12 Yusuf, Psikologi Belajar Agama: Prespektif Pendidikan Agama Islam. hlm. 53. 


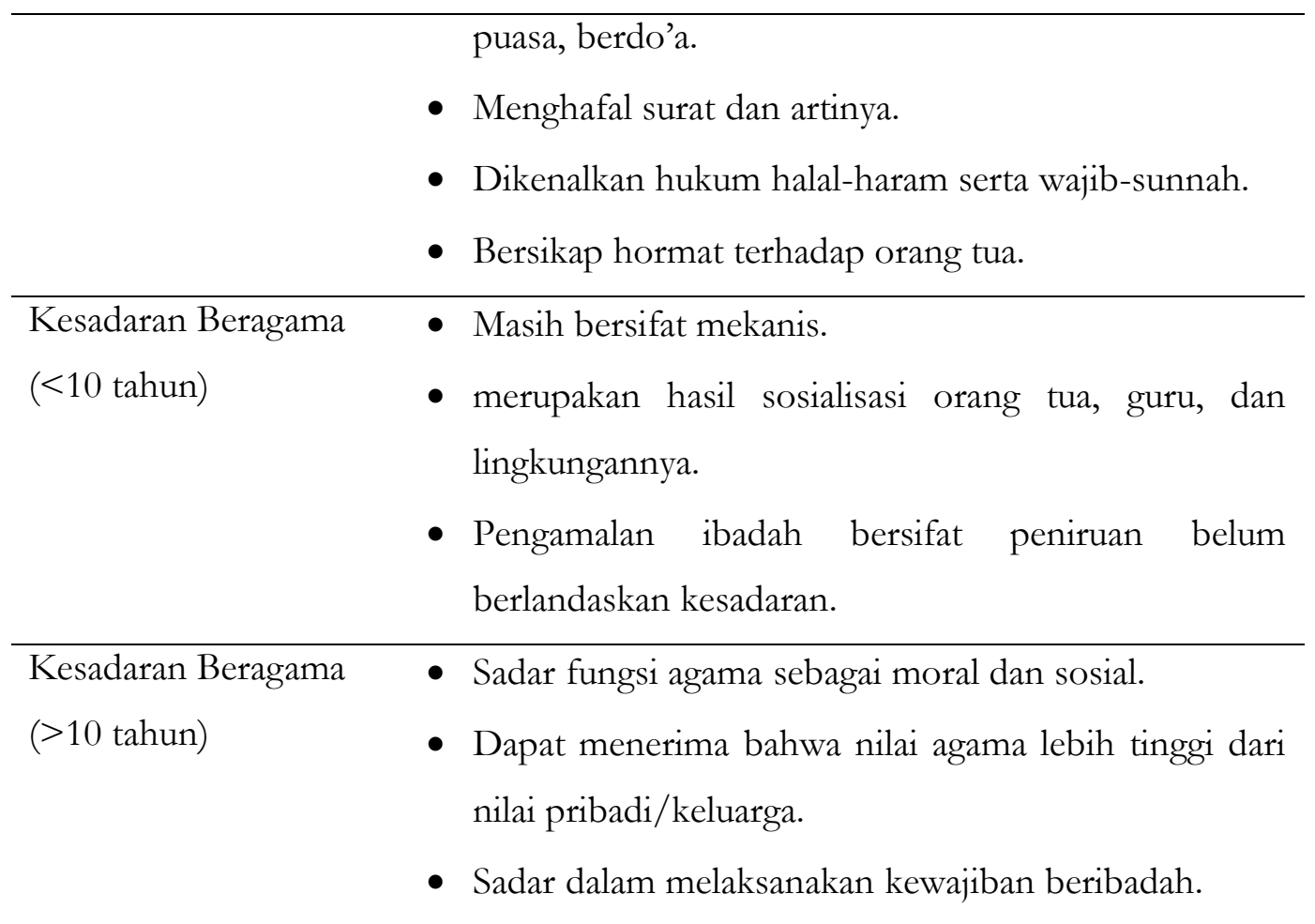

Tahapan perkembangan moral diklasifikasikan oleh Kohlberg dalam 3 tingkat dan 6 tahap. Kohlberg menjelaskan tahap perkembangan moral terjadi dari aktivitas spontan dari anak-anak yang berkembang melalui interksi sosial, namun interaksi ini mempunyai corak yang khusus dimana faktor pribadi yaitu aktivitas anak ikut berperan. Hal penting lain dari teori perkembangan moral Kohlberg ini adalah orientasinya untuk mengungkapkan moral yang hanya ada dalam pikiran dan yang dibedakan dengan tingkah laku moral dalam arti perbutan yang nyata ${ }^{13}$ dengan semakin tingginya tahap perkembangan moral seseorang akan semakin terlihat moralitas yang lebih tinggi pula.

Tabel 3. Tingkat dan Tahap Perkembangan Moral Menurut Kohlberg' ${ }^{14}$

\begin{tabular}{llll}
\hline \multicolumn{2}{c}{ Tingkat } & \multicolumn{2}{c}{ Tahap } \\
\hline 1. Prakonvensional Moralitas & 1. & Orientasi & Kepatuhan dan \\
Pada tahap ini anak mengenal & Hukuman & \\
moralitas berdasarkan dampak yang & Pemahaman anak tentang baik dan \\
ditimbulkan oleh suatu perbuatan & buruk ditentukan oleh otoritas. \\
(hadiah/hukuman). Anak tidak & Kepatuhan terhadap aturan untuk \\
melanggar aturan karena takut & menghindari hukuman dari otoritas. \\
hukuman. & & 2. & Orientasi relativis-Instrumental \\
\hline
\end{tabular}

${ }^{13}$ Desmita, Psikologi Perkembangan. hlm. 151.

${ }^{14}$ L Kohlberg, Tahap-tahap Perkembangan Moral (Yogyakarta: Kanisius, 1995). 
Iswatun K., Ifat N., Suyadi, Analisis Perkembangan Nilai Agama-moral Siswa Usia Dasar (tercapai)...

Hubungan antar manusia yang
terdapat elemen resiprositas dan
pembagian sama rata.

\section{Konvensional}

Suatu perbuatan dinilai baik oleh anak apabila mematuhi harapan otoritas keluarga, kelompok sebaya.

\section{Pasca-Konvensional}

Pada level ini aturan dan intuisi dari masyarakat tidak dipandang sebagai tujuan akhir, tetapi diperlukan sebagai subjek. Anak menghindari hukuman kata hati.
3. Orientasi anak yang baik "anak manis"

Tindakan berorientasi perilaku yang baik dan menyenangkan orang lain.

\section{Orientasi keteraturan dan otoritas}

Perilaku yang baik adalah sematamata melakukan kewajiban, menghormati otoritas dan menjaga ketertiban sosial.

\section{Orientasi kontrol sosial-legalistik} Semacam telah ada kesepakatan dengan seluruh masyarakat. Terdapat kesadaran yang jelas untuk relativisme nilai dan pendapat pribadi.

\section{Orientasi kata hati/prinsip} universal

Kebenaran ditentukan oleh kata hati, sesuai dengan prinsip etika universal yang bersifat abstrak dan penghormatan terhadap martabat manusia.

\section{METODE PENELITIAN}

Penelitian ini merupakan penelitian kualitatif deskriptif, dimana penelitian ini bertujuan untuk mendeskripsikan dan menganalisis data deskriptif yang dihasilkan yang berupa kata-kata dari orang-orang dan perilaku yang dapat diamati. Data yang diambil berdasarkan studi lapangan yang dilakukan peneliti. Penggunaan studi lapangan ini dikarenakan dengan studi lapangan peneliti dapat mendapatkan informasi dari narasumber terkait perkembangan nilai agama dan moral anak usia dasar yang tercapai.

\section{Copyright () 2019 Schemata Journal}


Iswatun K., Ifat N., Suyadi, Analisis Perkembangan Nilai Agama-moral Siswa Usia Dasar (tercapai)...

Dalam pengumpulan data, peneliti menggunakan teknik wawancara yang merupakan cara untuk memperoleh data dari narasumber atau responden yang menjadi objek penelitian. Wawancara juga sebagai teknik untuk mengetahui karakteristik anak, wawancara ini dilakukan dengan obrolan ringan tetapi bermakna untuk menggali informasi. Pada teknik wawancara ini, peneliti melakukan wawancara kepada guru, dan anak didik yang bersangkutan guna mengetahui bagaimana perilaku dan sikap perkembangan nilai agama dan moral yang tercapai pada anak usia sekolah dasar, dari segala kegiatan di sekolah, di rumah dan di lingkungan bermain anak. Peneliti juga melakukan kajian pustaka dari berbagai sumber untuk melengkapi dan mempertajam data-data yang terkait dengan topik yang dibahas.

\section{HASIL DAN PEMBAHASAN}

1. Analisis Perkembangan nilai agama dan moral anak yang tercapai di MI Ma'arif Bego, Sleman Yogyakarta

Analisis perkembangan nilai agama dan moral yang tercapai pada subjek ini hanya dilakukan berdasarkan usia subjek kelas atas di Madrasah Ibtidaiyah karena subjek yang diteliti duduk di kelas 6 dan berusia 12 tahun adalah sebagai berikut:

a. Perkembangan agama anak dengan subjek yang duduk di kelas 6 dengan usia 12 tahun

Berdasarkan tabel 1di atas dapat ditarik kesimpulan bahwa anak usia akhir masa anak-anak dapat dikategorikan pada pada Tahap 2: Mythical-literal faith. Merupakan masa anak pada usia 12 tahun memiliki karakteristik pemikiran yang lebih logis dan konkrit, menginterpretasikan kisah agama secara harfiah dan menggambarkan figur tuhan sebagai orang tua.

Berdasarkan wawancara dengan guru, didapatkan bahwa subjek memang mencapai tahap Mythical-literal faith. Didukung dengan guru memilih anak tersebut sebagai subjek dengan kategori agama dan moral yang tercapai. Subjek memiliki karakteristik yang sesuai dengan perkembangan agama menurut James Fowler di atas berdasarkan usia subjek.

Dikatakan oleh Elizabeth B. Hurlock dalam bukunya, dengan meningkatnya pemahaman dan keragaman pengalaman, konsep mereka berubah. Contohnya konsep Tuhan sebagai orang tua, akan dipengaruhi pengalaman dengan ayah mereka sendiri dan pengalaman teman mereka. Kemudian dengan bertambahnya

\section{Copyright () 2019 Schemata Journal}

Available online at http://journal.uinmataram.ac.id/index.php/schemata 
Iswatun K., Ifat N., Suyadi, Analisis Perkembangan Nilai Agama-moral Siswa Usia Dasar (tercapai)...

usia, kemampuan penalaran mereka meningkat, pengalaman meluas, belajar dari pengalaman, dan fakta-fakta yang sering bertentangan dengan apa yang telah dipelajari. Kemungkinan mereka juga menemukan perbedaan konsep dengan teman-teman yang lain. ${ }^{15}$

Senada dengan deskripsi di atas, berdasarkan hasil wawancaa dengan subjek, bahwa subjek memiliki pemikiran yang logis dan konkrit, hal itu dapat dijelaskan oleh subjek dimana subjek sadar dengan yang dilaksanakan sehari-hari, bagaimana konsep antara teori dengan praktik nyata terkait nilai agama serta pengamalannya dan menjadikan orang tua sebagai teladan bagi subjek.

\section{b. Perkembangan kesadaran beragama anak berdasarkan nilai-nilai agama pada subjek}

1) Aqidah

Pada nilai-nilai aqidah, sikap dan perilaku subjek telah mencapai indikator yang dipaparkan pada tabel 2 di atas. Berdasarkan hasil wawancara dengan subjek, subjek telah merasakan adanya kebutuhan dalam berkeyakinan, subjek memahami akan adanya sifat Tuhan yang Maha Pengasih dan Penyayang. Subjek juga memahami jika melanggar aturan Allah akan mendapatkan dosa dan siksa di neraka. Dengan demikian nilai-nilai agama tentang aqidah sudah dicapai oleh subjek. Ketika diminta untuk memberikan contoh subjek menjelaskan saat lupa melaksanakan sholat atau terlambat subjek merasa bersalah.

2) Ibadah dan Akhlak

Pada nilai-nilai ibadah dan akhlak, sikap dan perilaku subjek telah mencapainya meskipun belum sepenuhnya. Berdasarkan hasil wawancara dengan subjek, subjek telah menguasai dan mengembangkan materi dari pendidikan sebelumnya. Dalam pembiasaan beribadah ritual, kewajiban seperti sholat, puasa dan berdo'a telah dilaksanakan dengan tertib, ditambah pembiasaan dari kebijakan sekolah untuk melaksanakan sholat dhuha setiap pagi di sekolah. Hafalan surat beserta artinya juga menjadi suatu aspek yang telah dicapai subjek berdasarkan kegiatan disekolah. Subjek juga telah mengenal hukum halal-haram serta wajib-sunnah. Terkait sikap hormat terhadap orang tua, subjek menjelaskan jika ia patuh pada orang tua,

${ }^{15}$ E. B Hurlock, Perkembangan Anak, Jilid II. (Jakarta: Erlangga, 1993). 
Iswatun K., Ifat N., Suyadi, Analisis Perkembangan Nilai Agama-moral Siswa Usia Dasar (tercapai)...

menyadari akan tanggungjawabnya sebagai anak, menghormati orang tua namun dalam berbahasa kepada orang tua belum menggunakan bahasa jawa yang halus karena lebih sering menggunakan bahasa Indonesia.

3) Kesadaran Beragama

Pada nilai kesadaran beragama kita mengacu pada usia di atas 10 tahun, dimana subjek berusia 12 tahun. Berdasarkan hasil wawancara, subjek telah mencapai nilai kesadaran dalam beragama sebagai nilai dalam moral dan sosialnya. Subjek juga menerima bahwa agama adalah kepercayaan masyarakat, seperti halnya pelaksanaan ibadah sholat berjamaah, sholat hari raya dan ibadah sosial menjadi hal yang menarik, namun ketika dirumah praktik sholat berjamaah belum maksimal dilaksanakan. Subjek juga menyadari bahwa melaksanakan kewajiban adalah suatu ibadah meskipun terkaang masih diingatkan dalam pelaksanaannya.

\section{c. Perkembangan moral anak berdasarkan teori perkembangan moral Kohlberg}

Anak usia kelas atas Sekolah Dasar (subjek kelas 6 usia 12 tahun) dapat dikategorikan dalam tingkat konvensional pada tahap 3 dan 4. Kohlberg meyakini bahwa tingkatan dan tahapan ini terjadi secara berurutn sesuai dengan usia. Sebelum usia 9 tahun, anak menggunakan tingkat 1, dan ketika akhir masa anakanak menuju awal remaja, kebanyakan mereka telah mencapai tingkat 2 yaitu konvensional. ${ }^{16}$

Fase konvensional ini dibagi menjadi 2 tahap, yakni tahap ketiga: orientasi anak yang baik terkait hubungan dengan orang lain dimana anak menyadari perilaku yang bermoral akan berdampak kepada orang lain dan harus menyenangkan orang lain. Subjek menjelaskan bahwa dalam berhubungan dengan orang lain perlu memperhatikan kepercayaan, kepedulian, saling berbagi dan tidak memilih teman bergaul. Berbagai hal tersebut sudah sesuai dengan teori yang ditetapkan oleh Kohlberg. Pada tahap keempat: dalam bersikap dan berperilaku, ada aturan atau standar tertentu yang telah ditetapkan masyarakat maupun pemerintah. Dalam hal ini subjek telah mencapainya dengan mematuhi peraturan yang ada dalam masyarakat seperti rutin mendatangi TPA di lingkungan rumah serta aturan-aturan lainnya.

16Amrah, "Perkembangan Moral Anak Usia Sekolah Dasar," Publikasi Pendidikan (2013). hlm. 23. 
Iswatun K., Ifat N., Suyadi, Analisis Perkembangan Nilai Agama-moral Siswa Usia Dasar (tercapai)...

Subjek dapat menyebutkan beberapa peraturan kelas yang tidak boleh dilanggar, antara lain: dilarang tidur di kelas selama jam pelajaran berlangsung, tidak boleh membuat gaduh di kelas, dilarang menyontek hasil pekerjaan teman sekelas (tugas individu), tidak mengerjakan pekerjaan rumah, tidak melaksanakan piket kelas yang telah terjadwal, bercengkerama dengan teman sebangku ketika guru menjelaskan.

Subjek pernah melanggarnya, yakni bercengkerama dengan teman sebangku ketika guru sedang menerangkan. Tapi itu dulu ketika kelas 3, seiring bertambahnya umur, kedewasaan berpikir dan moral peserta didik, maka hal tersebut tidak pernah terulangi lagi, termasuk pelanggaran lainnya, sampai sekarang kelas 6. Ada dampak positif walau kecil ketika anak tersebut melakukan pelanggaran kemudian dihukum dengan menulis latin "saya tidak akan mengulangi lagl” pada selembar kertas penuh. Ada efek jera karena harus menulis latin berulangkali serta malu karena teman sekelasnya tahu bahwa Alifia dihukum guru karena bercengkerama ketika guru sedang menerangkan.

\section{Analisis faktor perkembangan tercapainyanilai agama dan moral anak di MI Ma'arif Bego, Sleman Yogyakarta}

Berdasarkan hasil analisis perkembangan nilai agama-moral anak di atas, secara garis besar dapat ditarik kesimpulan adanya beberapa faktor yang mempengaruhi tercapainya perkembangan nilai agama-moral pada anak usia sekolah dasar. Adapun faktor tercapainya nilai agama-moral anak pada subjek dapat digambarkan sebagai berikut:

Gambar 1. Faktor Tercapainya Perkembangan Nilai Agama-Moral Subjek

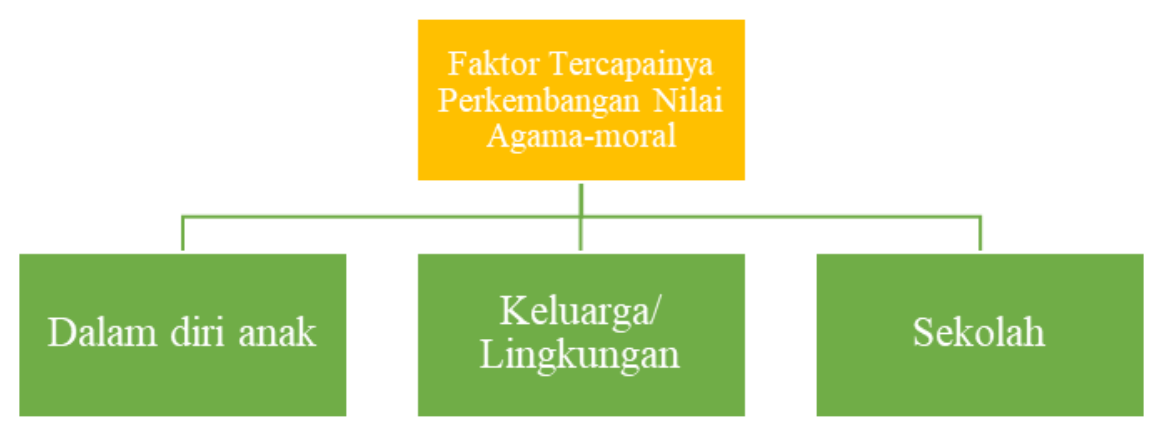

Gambar di atas menunjukkan bahwa fator pendukung tercapainya nilai agamamoral anak pada subjek ada 3 faktor yakni dalam diri anak, keluarga/lingkungan, dan sekolah. Deskripsi dari ketiga faktor tersebut adalah sebagai berikut:

\section{Copyright () 2019 Schemata Journal}

Available online at http://journal.uinmataram.ac.id/index.php/schemata 
Iswatun K., Ifat N., Suyadi, Analisis Perkembangan Nilai Agama-moral Siswa Usia Dasar (tercapai)...

Dikemukakan oleh Yusuf (2012), faktor genetik/hereditas merupakan faktor internal yang berpengaruh terhadap pertumbuhan dan perkembangan individu. Hereditas sendiri dapat diartikan sebagai totalitas karakteristik individu yang diwariskan orang tua. Sejalan dengan itu, faktor genetik dapat diartikan sebagai segala potensi (baik fisik maupun psikis) yang dimiliki individu sejak masa pra kelahiran sebagai pewarisan dari pihak orang tua melalui gen-gen. Dari definisi tersebut, yang perlu digaris bawahi adalah faktor ini bersifat potensial, pewarisan/bawaan dan alamiah (nature). ${ }^{17}$

b. Keluarga/lingkungan

Konsep ajaran Islam menegaskan bahwa pada hakikatnya jin dan manusia adalah untuk menjadi pengabdi yang setia kepada Penciptanya (Q.S. Adz-Dzariyat: 56). Agar tugas dan tanggungjawab tersebut dapat diwujudkan secara benar, Tuhan mengutus Rasul-Nya sebagai pemberi pengajaran, contoh, dan teladan. Dalam estafet berikutnya, risalah kerasulan itu diwariskan kepada para ulama. Akan tetapi tanggung jawab utamanya dititikberatkan pada orangtua. ${ }^{18}$

Dalam hal ini, orang tua Alifia dari kecil hingga sekarang selalu mengajarkan hal-hal yang berkaitan dengan agama, baik itu hal-hal yang diwajibkan maupun yang dilarang oleh agama. Peran orang tua dalam membimbing agama anaknya adalah agar anaknya berada di “jalan yang benar". Pembimbingan tersebut merupakan bukti bahwa keluarga merupakan pendidik dasar yang pertama bagi anak-anaknya. Pendidikan keluaga juga merupakan pendidik dasar bagi pembentukan jiwa keagamaan pada anak, dalam hal ini orang tua maupun keluarga inti.

Dorongan keberagamaan merupakan faktor bawaan manusia. Apakah setelah dewasa seseorang kelak akan menjadi sosok penganut agama yang taat atau tidak, hal itu sepenuhnya bergantung pada pembinaan nilai-nilai agama oleh kedua orangtua. Karena keluarga merupakan pendidikan dasar yang pertama bagi anakanak, lembaga pendidikan merupakan penerus dan penguat dari pondasi.

c. Sekolah

17 U Latifa, “Aspek Perkembangan pada Anak Sekolah Dasar: Masalah dan Perkembangannya," Academia Vol 1 No.2 (2017). hlm. 190.

18 B. S Arifin, Psikologi Agama (Bandung: Pustaka Setia, 2008). hlm. 52. 
Iswatun K., Ifat N., Suyadi, Analisis Perkembangan Nilai Agama-moral Siswa Usia Dasar (tercapai)...

Lembaga pendidikan merupakan pelanjut dari pendidikan rumah tangga. Madrasah Ibtidaiyah Ma'arif Bego pun di sini punya peran yang cukup penting juga karena mengajarkan agama secara lebih luas melalui mata pelajaran agamanya seperti tarikh, bahasa arab, aqidah akhlak, Al-Qur'an Hadits, serta Fiqih. Selain itu, kegiatan ektra kulikulernya yang mendukung seperti BTQH, Qiro'ati dansebaginya. Selain itu, guru-gurunya selain mengajarkan juga mencontohkan serta lingkungan sekolah yang mendukung untuk perkembangan agama Alifia dan teman-temannya.

Perkembangan agama yang dapat tercapai dengan baik pada anak-anak usia sekolah dasar dapat menghindarkan diri dari perilaku-perilaku penyimpangan agama seperti kenakalan remaja, penggunaan narkotika, zat adiktif, dan minuman keras, perilaku free seks, pelacuran, sodomi, homoseks serta lesbian. ${ }^{19}$

Gejala yang tampak pada perkembangan nilai, moral dan sikap, antara lain:

a. Terbentuknya pandangan hidup yang semakin jelas dan tegas.

b. Berkembangnya pemahaman tentang apa yang baik dan seharusnya dilakukan serta apa yang dianggap tidak baik dan tidak boleh dilakukan.

c. Berkembangnya sikap untuk menghargai nilai-nilai dan norma-norma yang berlaku seta mewujudkannya ke dalam kehidupan sehari-hari.

d. Berkembangnya sikap menentang terhadap kebiasaan-kebiasaan yang dianggap tidak sesuai dengan norma yang berlaku. ${ }^{20}$

\section{KESIMPULAN}

Apabila pada masa kanak-kanak sudah tertanam konsep konsep kesusilaan atau dalam istilah lain sering disebut dengan moral. Peran keluarga, sekolah dan lingkungan dalam mengajarkan nilai-nilai moral dan agama kepada anak sebagai bekal dalam menjalani masa remajanya dan seterusnya.

Faktor pendukung tercapainya nilai agama-moral anak pada subjek ada 3 faktor, yakni: internal/dari dalam diri anak, keluarga/lingkungan, dan sekolah. Ketiga faktor tersebut harus saling mendukung, mengawasi, mengingatkan, membimbing, memberi contoh serta menjaga satu sama lain agar tercipta generasi penerus bangsa yang taat beragama dan bermoral tinggi.

\footnotetext{
${ }^{19}$ Khairunnas, Psikologi Agama (Yogyakarta: Aswaja Presindo, 2012). hlm. 73.

${ }^{20}$ Asrori, Psikologi Pembelajaran. hlm. 37.
} 
Iswatun K., Ifat N., Suyadi, Analisis Perkembangan Nilai Agama-moral Siswa Usia Dasar (tercapai)...

Dengan tercapainya nilai agama dan moral pada siswa usia dasar, maka akan menjauhkan siswa usia dasar dari perilaku maupun hal-hal yang menyimpang, seperti: bullying, mencuri, merokok, berani melawan orangtua, tidak menghormati guru serta yang memprihatinkan saat ini adalah perilaku seks bebas dan narkoba.

\section{DAFTAR PUSTAKA}

Amrah. (2013). Perkembangan Moral Anak Usia Sekolah Dasar. Publikasi Pendidikan, 2025.

Arifin, B. S. (2008). Psikologi Agama. Bandung: Pustaka Setia.

Asrori, M. (2012). Psikologi Pembelajaran. Bandung: CV Wacana Prima.

Damanik, C. (2018). https://wnw.kompas.com/. Diambil kembali dari https://regional.kompas.com/read/2018/01/29/10365701/gara-gara-cetak-golbunuh-diri-siswa-sd-dianiaya-teman-teman-hingga-masuk

Desmita. (2006). Psikologi Perkembangan. Bandung: PT Remaja Rosda Karya.

Hurlock, E. B. (1993). Perkembangan Anak Jilid II. Jakarta: Erlangga.

Khairunnas. (2012). Psikologi Agama. Yogyakarta: Aswaja Presindo.

Kohlberg, L. (1995). Tahap-tahap Perkembangan Moral. Yogyakarta: Kanisius.

Kurtinez, W. (1992). Moralitas, Perilaku Moral dan Perkembangan Moral. Jakarta: UI Press.

Kusrahmadi, S. D. (2007). Pentingnya Pendidikan Moral Bagi Anak Sekolah Dasar. Dinamika Pendidikan, 118-129.

Latifa, U. (2017). Aspek Perkembangan pada Anak Sekolah Dasar: Masalah dan Perkembangannya. Academia 1(2), 190.

Muslih. (1987). Moral Agama, Sulub Kepribadian Pemuda Menghadapi Arus Budaya Massa. Dirjen Bimbaga Islam.

Winkel, W. (1996). Psikologi Pengajaran. Jakarta: Grasindo.

Yusuf, S. (2005). Psikologi Belajar Agama: Prespektif Pendidikan Agama Islam. Bandung: Pustaka Bani Quraisy.

Yusuf, S. (2016). Psikologi Perkembangan Anak dan Remaja. Bandung: PT Remaja Rosda Karya. 